\title{
Terapi Medikamentosa pada Paralisis Saraf Fasialis Akibat Fraktur Tulang Temporal
}

\author{
Jacky Munilson, Yan Edward, Dedy Rusdi
}

\begin{abstract}
Abstrak
Pendahuluan: Paralisis saraf fasialis merupakan salah satu komplikasi fraktur tulang temporal. Fraktur tulang temporal dapat berupa fraktur longitudinal, transversal maupun campuran. Paralisis saraf fasialis lebih banyak ditemukan pada fraktur tulang transversal dibandingkan longitudinal. Penatalaksanaan paralisis saraf fasialis akibat fraktur tulang temporal masih kontroversi, dapat berupa terapi medikamentosa maupun terapi bedah. Metode: Satu kasus paralisis saraf fasialis akibat fraktur temporal longitudinal tahun yang ditatalaksana dengan terapi medikamentosa. Hasil: Terdapat peningkatan fungsi saraf pasialis dengan terapi medikamentosa pada paralisis parsial saraf fasialis akibat fraktur temporal longitudinal. Diskusi: Penatalaksanaan paralisis saraf fasialis akibat fraktur tulang temporal masih merupakan hal yang kontroversial. Pasien dengan paralisis parsial (House Brackmann II-V) cukup dilakukan observasi dan terapi dengan steroid berupa prednison, sedangkan pada paralisis komplit (House Brackmann VI), terapi medikamentosa dengan steroid dapat dikombinasikan dengan terapi bedah berupa dekompresi atau grafting. Pertimbangan untuk melakukan pembedahan tergantung dari pemeriksaan CT Scan dan tes elektrofisiologis
\end{abstract}

Kata kunci: Paralisis saraf fasialis, fraktur tulang temporal, terapi medikamentosa

\begin{abstract}
Facial nerve paralysis is one of the temporal bone fracture complications. Temporal bone fracture is classified as longitudinal, transversal and mixed type. Facial nerve paralysis is more common in transversal rather than longitudinal type. The treatment of facial nerve paralysis due to temporal bone fracture still remain controversial, whether its medical therapy or surgical approach.Methode: One case of facial nerve paralysis caused by longitudinal type of temporal bone fracture has been treated by medical therapy. Result: There is an increase of facial nerve function treated with medical therapy in a case of partial nerve paralysis due to longitudinal type of temporal bone fracture. Discussion: Management of facial nerve paralysis due to temporal bone fracture is still controversial. Patient with partial paralysis (House Brackmann II-V) treated with observation and medical therapy using steroid, whereas complete paralysis (House Brackmann VI) treated with medical therapy using steroid, combine with decompression and grafting surgery. Considerations for surgery depend on computed tomography and electrophysiology examination.
\end{abstract}

Keywords: Facial nerve paralysis, temporal bone fracture, medical therapy

Affiliasi penulis : Bagian Telinga Hidung Tenggorok Bedah Kepala Leher (THT-KL) Fakultas Kedokteran Universitas Andalas Padang. Korespondensi : Jacky Munilson, E-mail: jackymunilson@yahoo.co.id, Telp: 0751-810900

\section{PENDAHULUAN}

Saraf fasialis merupakan saraf yang kompleks dan memiliki keunikan dalam hal fungsi maupun anatomi, sehingga sering terlibat pada patologi kepala-leher diantaranya karena trauma. ${ }^{1-3}$ Trauma pada saraf fasialis merupakan kasus terbanyak kedua sebagai penyebab paralisis saraf fasialis setelah Bell's Palsy. ${ }^{1,2}$

Secara anatomi, saraf fasialis terbagi atas 3 segmen yaitu intrakranial, intratemporal dan ekstratemporal. Lokasi terbanyak paralisis saraf fasialis akibat trauma adalah intratemporal. Terdapat beberapa jenis trauma pada tulang temporal yang 
menyebabkan paralisis saraf fasialis yaitu fraktur tulang temporal, trauma tembus dan trauma iatrogenik. Fraktur tulang temporal merupakan penyebab terbanyak paralisis saraf fasialis. ${ }^{3}$

Fraktur tulang temporal dapat berupa fraktur longitudinal, transversal maupun campuran. Fraktur longitudinal merupakan jenis fraktur yang terbanyak ditemukan yaitu sekitar $70-80 \%$ dari semua kasus fraktur temporal, sedangkan jenis transversal sekitar $10-20 \%$. Paralisis saraf fasialis pada fraktur longitudinal ditemukan sekitar 25\% kasus, sedangkan pada fraktur transversal ditemukan lebih banyak yaitu sebesar $50 \%$. $^{3-8}$

\section{LAPORAN KASUS}

Seorang laki-laki umur 33 tahun, datang ke IGD RS Dr. M. Djamil Padang pada tanggal 22 Oktober 2011 rujukan dari dokter spesialis THT-KL RSUD Sungai Penuh dengan diagnosis paralisis saraf fasialis dekstra + laserasi liang telinga $A D$ et causa trauma tumpul. Dua hari sebelum masuk rumah sakit, pasien sedang bekerja di pinggir sungai, tiba-tiba sebatang kayu menggelinding ke arah pasien dan mengenai kepala dan telinga bagian kanan. Pasien tetap sadar setelah kejadian. Terdapat darah keluar dari telinga kanan, tetapi dari mulut dan hidung tidak ada. Terdapat luka robek di depan telinga kanan. Terdapat nyeri kepala, tidak ada kejang, pusing berputar, mual dan muntah. Pendengaran pada telinga kanan berkurang, tidak ada riwayat keluar cairan dan darah dari telinga sebelumnya. Wajah terlihat mencong. Luka di depan telinga dijahit dan pasien dirawat di RSUD Sungai Penuh selama 2 hari. Pasien dikonsulkan ke dokter spesialis THT-KL, kemudian dipasang tampon pada telinga kanan dan pasien dirujuk ke RS Dr. M. Djami Padang.

Pada pemeriksaan fisik didapatkan keadaan umum baik, kesadaran komposmentis kooperatif, tidak demam. Pada pemeriksaan telinga luar terdapat vulnus ekskoriasi dan vulnus laseratum yang telah dijahit ukuran $3 \mathrm{~cm}$ pada preaurikuler dekstra. Pada liang telinga kanan terpasang tampon sofratulle, setelah tampon diangkat terlihat liang telinga sempit, clotting (+), darah mengalir (-), tampak edema dan hematom pada bagian anteroinferior dan laserasi pada bagian posterosuperior, membran timpani sukar dinilai. Pada pemeriksaan telinga kiri, hidung dan tenggorok tidak ditemukan kelainan. Pemeriksaan tes penala didapatkan Rinne pada telinga kanan negatif, telinga kiri positif, Weber lateralisasi ke kanan, Schwabach telinga kanan memanjang, telinga kiri sama dengan pemeriksa. Kesan tuli konduktif telinga kanan.

Pada pemeriksaan fungsi saraf fasialis perifer dekstra dengan metode Freys didapatkan fungsi motorik otot-otot wajah dengan nilai 18 , tonus otot 10 , sinkinesis 5, tidak ditemukan hemispasme. (Gambar 1). Pada pemeriksaan topografi saraf fasialis yaitu tes Schimmer tidak ditemukan perbedaan produksi air mata kiri dan kanan tes pengecapan sederhana didapatkan fungsi pengecapan kanan menurun.
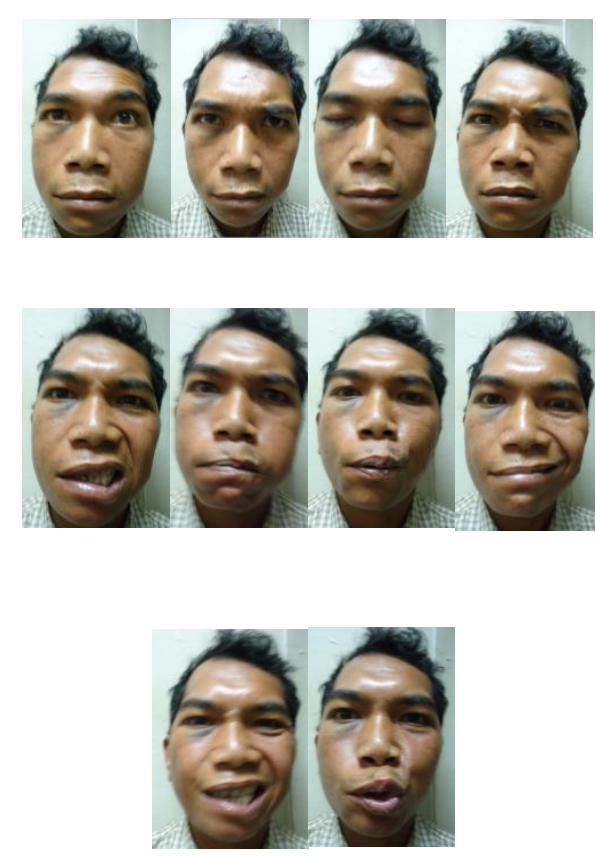

Gambar 1. Pemeriksaan fungsi motorik pada saat pasien pertama kali datang

Pemeriksaan gradasi kerusakan saraf fasialis dengan metode House Brackmann didapatkan pada keadaan istirahat terlihat simetris kiri dan kanan, gerakan dahi kanan tertinggal, mata tertutup sempurna dengan usaha, gerakan mulut asimetris. Tes keseimbangan sederhana didapatkan hasil dalam batas normal. Pemeriksaan laboratorium dalam batas normal. Pasien didiagnosis dengan paralisis saraf fasialis perifer dekstra dengan fungsi motorik yang masih baik 66\%, House Brackmann III dengan lesi setinggi infragenikulatum + laserasi liang telinga AD et causa suspek fraktur temporal dekstra. 
Pasien dirawat di bangsal THT-KL, dipasang tampon sofratulle pada liang telinga kanan, diberikan terapi injeksi seftriakson $2 \times 1 \mathrm{gr}$, injeksi deksametason $3 \times 2$ ampul tappering off, kapsul mecobalamin $3 \times 500$ mcg, asam mefenamat $3 \times 500 \mathrm{mg}$ dan neurotropik $2 \times 1$ tablet.

Pada tanggal 24 Oktober 2011 (hari ke-2 rawatan), keadaan umum pasien baik, kesadaran komposmentis kooperatif, suhu afebris, masih terdapat wajah mencong, tidak ada pusing berputar, nyeri kepala, mual dan muntah serta keluar darah dari telinga. Pada pemeriksaan telinga luar, vulnus ekskoriasi dan vulnus laseratum yang telah dijahit pada preaurikuler dekstra kering. Liang telinga terpasang tampon sofratulle, tidak terdapat darah dan cairan yang merembes, serta tidak berbau.

Pada pemeriksaan saraf fasialis dengan metode Freys didapatkan fungsi motorik otot-otot wajah dengan nilai 19 , tonus 10 , sinkinesis 5 , tidak ditemukan hemispasme. Tes gustatometri dan Schimmer serta pemeriksaan metode House Brackmann sama dengan pemeriksaan sebelumnya. Didapatkan kesimpulan paralisis saraf fasialis perifer dekstra dengan fungsi motorik yang masih baik $68 \%$, House Brackmann III, dengan lesi setinggi infragenikulatum. Terapi dilanjutkan.

Pada tanggal 25 Oktober 2011 (hari ke-3 rawatan) dilakukan pengangkatan tampon sofratulle pada telinga kanan, tampak clotting, tidak ada darah dan sekret, liang telinga udema, laserasi pada posterosuperior, hematom pada anteroinferior berkurang, keseluruhan membran timpani sukar dinilai, tetapi tampak gambaran hemotimpanum. Vulnus ekskoriasi dan vulnus laseratum yang telah dijahit pada preaurikuler dekstra tampak kering.

Pemeriksaan saraf fasialis sama dengan pemeriksaan hari sebelumnya. Pemeriksaan tes penala didapatkan Rinne pada telinga kanan negatif, telinga kiri positif, Weber lateralisasi ke kanan, Schwabach telinga kanan memanjang, telinga kiri sama dengan pemeriksa. Kesan tuli konduktif telinga kanan. Pada pemeriksaan audiometri, didapatkan kesan telinga kanan tuli konduksi derajat sedang ambang dengar 43,75 dB dan telinga kiri normal dengan ambang dengar 17,5 dB (Gambar 2).

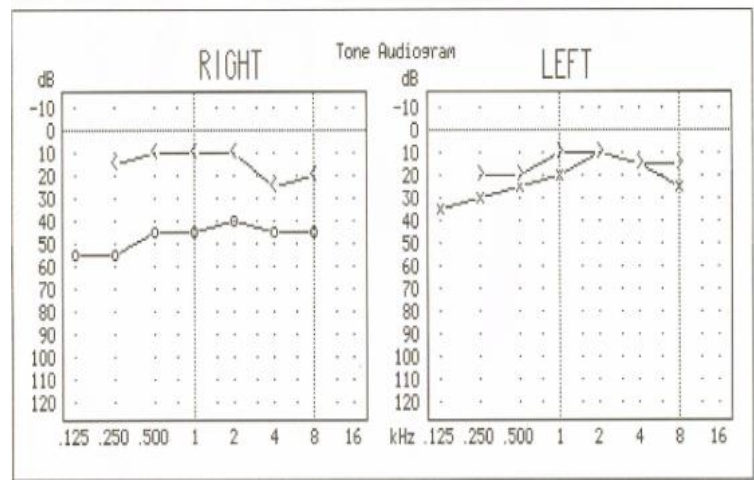

Gambar 2. Pemeriksaan audiometri pada rawatan hari ke-3

Pemeriksaan timpanometri dan refleks stapedius tidak dilakukan karena adanya laserasi dan udema pada liang telinga.

Pada CT Scan mastoid potongan aksial dan koronal irisan $2 \mathrm{~mm}$ soft tissue setting (gambar 2), tampak fraktur mastoid dan fossa temporal kanan, tampak perselubungan di rongga mastoid kanan, kesaan fraktur basis cranii. Pasien didiagnosis dengan paralisis saraf fasialis perifer dekstra dengan fungsi motorik yang masih baik 68\%, House Brackmann III dengan lesi setinggi infragenikulatum + laserasi liang telinga + hemotimpanum $A D$ et causa fraktur longitudinal tulang temporal.

Tampon sofratulle dipasang kembali dan dilakukan pengangkatan jahitan selang-seling. Diberikan terapi seftriakson 2x1 gr, deksametason $2 \times 2$ ampul, kapsul mekobalamin $3 \times 500 \mathrm{mcg}$, neurotropik $2 \times 1$ tablet, ambroksol $3 \times 30 \mathrm{mg}$ dan loratadin $5 \mathrm{mg}$ + pseudoefedrin $\mathrm{HCl} 120 \mathrm{mg} 2 \times 1$ kapsul.

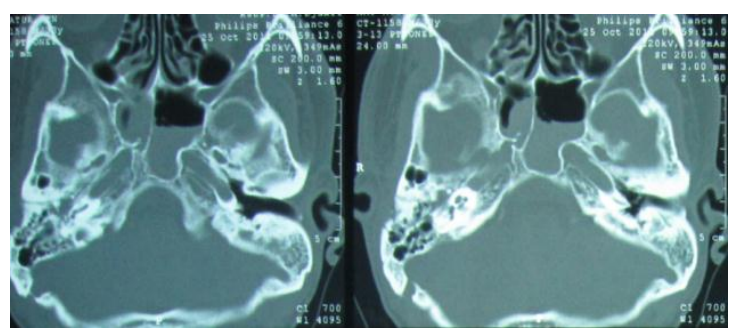

Gambar 3. CT Scan mastoid potongan aksial

Pada tanggal 27 Oktober 2011 (hari rawatan ke-5), masih terdapat wajah mencong, tidak ada pusing berputar, nyeri kepala, maupun mual dan muntah. Dilakukan pengangkatan tampon sofratulle pada liang telinga dan sisa jahitan pada preaurikuler 
dekstra. Tampak liang telinga masih udem, laserasi pada superoposterior dan hematom pada anteroinferior sudah berkurang, masih tampak hemotimpanum.

Pada pemeriksaan saraf fasialis didapatkan fungsi motorik membaik dengan nilai 20 , tonus 12 , sinkinesis 5, tidak ditemukan hemispasme. Pemeriksaan gustatometri dan Schimmer sama dengan pemeriksaan sebelumnya. Didapatkan kesimpulan paralisis saraf fasialis perifer dekstra dengan fungsi motorik masih baik 74\%, House Brackmann III, dengan lesi setinggi infragenikulatum. Tampon sofratulle dipasang kembali dan terapi dilanjutkan.

Pada tanggal 29 Oktober 2011 (hari ke-7 rawatan), pada pemeriksaan telinga luar terlihat luka jahitan di preaurikuler dekstra kering. Setelah tampon sofratulle diangkat, terlihat liang telinga masih udem, tidak tampak lagi hematom pada liang telinga, laserasi di superoposterior masih terlihat dan masih tampak hemotimpanum.

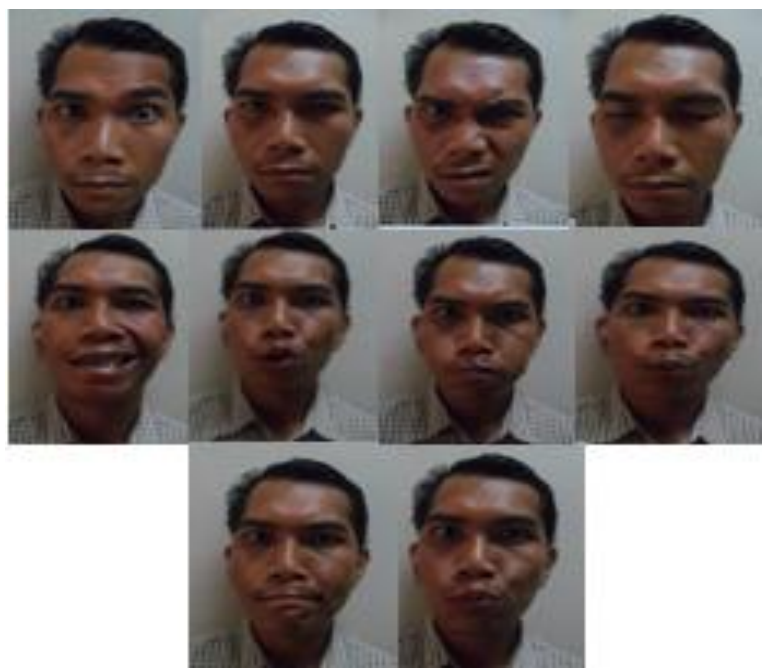

Gambar 4. Pemeriksaan fungsi motorik pada saat pasien pulang

Pada pemeriksaan saraf fasialis didapatkan fungsi motorik, tonus, sinkinesis dan hemispasme sama dengan pemeriksaan 2 hari sebelumnya. (Gambar 4). Pasien pulang paksa karena alasan tidak ada biaya. Tampon sofratulle dipasang kembali dan diberikan terapi tablet siprofloksasin 2x500 mg, kapsul mekobalamin $3 \times 500 \mathrm{mcg}$, pseudoefedrin 120 $\mathrm{mg}+$ loratadine $5 \mathrm{mg}$ 2x1 kapsul, ambroksol 3×30 mg dan neurotropik $2 \times 1$ tablet. Pasien disarankan untuk kontrol ke RSUD Sungai Penuh untuk buka tampon dan evaluasi selanjutnya.

Dari anamnesis melalui telepon pada tanggal 1 November 2011 pasien menjelaskan bahwa tampon di telinga telah diangkat tetapi tidak dipasang kembali dan diberi terapi medikamentosa. Pasien tidak mengeluhkan adanya pusing berputar, nyeri kepala, mual dan muntah. Tetapi wajah terlihat masih mencong dan masih terdapat gangguan pendengaran tetapi sudah berkurang. Satu minggu kemudian pasien kembali kontrol dan mendapat terapi 1 minggu. Setelah itu pasien tidak kontrol lagi.

Pada tanggal 21 Oktober 2012 (kurang lebih satu tahun setelah dirawat), dari hasil kunjungan ke rumah pasien, pasien mengeluhkan telinga kanan masih kurang mendengar tetapi lebih baik dibandingkan satu tahun lalu. Pada pemeriksaan telinga kanan didapatkan liang telinga sempit, terdapat jaringan sikatrik pada bagian posterosuperior liang telinga sehingga membran timpani sukar dinilai secara keseluruhan. Pemeriksaan tes penala didapatkan Rinne pada telinga kanan negatif, telinga kiri positif, Weber lateralisasi ke kanan, Schwabach telinga kanan memanjang, telinga kiri sama dengan pemeriksa. Kesan tuli konduktif telinga kanan.

Pemeriksaan gradasi kerusakan saraf fasialis dengan metode House Brackmann didapatkan pada keadaan istirahat terlihat simetris kiri dan kanan, gerakan dahi normal, mata tertutup sempurna dengan usaha minimal, gerakan mulut sedikit asimetris. Pada pemeriksaan dengan metode Freys didapatkan fungsi motorik otot-otot wajah dengan nilai 28 , tonus 14 , sinkinesis 5, tidak ditemukan hemispasme. Tes Schimmer tidak ditemukan perbedaan produksi air mata kiri dan kanan, tes pengecapan sederhana didapatkan fungsi pengecapan kanan menurun. Didapatkan kesimpulan paralisis saraf fasialis perifer dekstra dengan fungsi motorik yang masih baik $94 \%$, 
House Brackmann II, dengan lesi setinggi infragenikulatum.
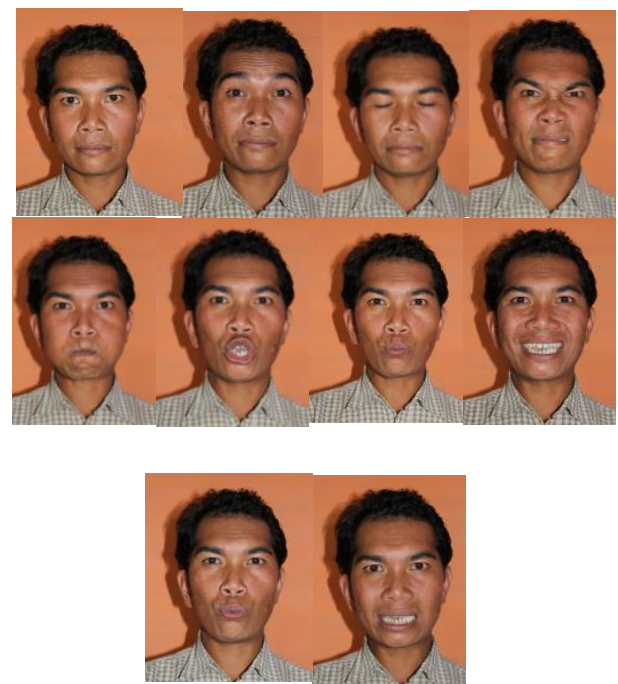

Gambar 5. Pemeriksaan fungsi motorik satu tahun setelah dirawat

\section{DISKUSI}

Telah dilaporkan satu kasus pasien yang didiagnosis dengan paralisis saraf fasialis akibat fraktur longitudinal tulang temporal. Diagnosis ditegakkan berdasarkan anamnesis, pemeriksaan fisik berupa pemeriksaan fungsi saraf fasialis dengan metode Freys dan House Brackmann, serta pemeriksaan penunjang berupa CT Scan. Pada kasus ini dilakukan penatalaksanaan dengan terapi medikamentosa.

Paralisis saraf fasialis merupakan suatu kasus yang relatif sering terjadi, diperkirakan terjadi 70 kasus per 100.000 populasi setiap tahun. Trauma akibat kecelakaan dan operasi merupakan penyebab kedua terbanyak paralisis saraf fasialis pada orang dewasa setelah Bell's Palsy. ${ }^{1}$ May dan Slein seperti yang dikutip oleh Mavrikakis ${ }^{9}$ menyatakan paralisis saraf fasialis akibat Bell's Palsy berkisar antara 49$51 \%$, sedangkan akibat trauma berkisar $8-22 \%$.

Saraf fasialis merupakan saraf kranial terpanjang yang berjalan di dalam tulang temporal, sehingga sebagian besar kelainan saraf fasialis terletak di dalam tulang temporal. Dalam perjalannnya di dalam tulang temporal, saraf fasialis dibagi dalam 3 segmen, yaitu segmen labirin, segmen timpani, dan segmen mastoid. Segmen labirin merupakan bagian terpendek (2-4 mm) terletak di antara akhir kanal akustikus internus dan ganglion genikulatum. Segmen timpani (panjang kira-kira $12 \mathrm{~mm}$ ) terletak di antara bagian distal ganglion genikulatum dan berjalan ke arah posterior telinga tengah, kemudian naik ke arah tingkap lonjong dan stapes, lalu turun dan kemudian terletak sejajar kanalis semisirkularis horizontal. Segmen mastoid merupakan segmen terpanjang (1,5$2 \mathrm{~cm}$ ) berjalan mulai dari dinding medial dan superior kavum timpani, selanjutnya berjalan ke arah kaudal menuju foramen stilomastoid. Setelah keluar dari dalam tulang mastoid, saraf fasialis menuju kelenjar parotis dan membagi diri untuk mensarafi otot-otot wajah. $^{10}$

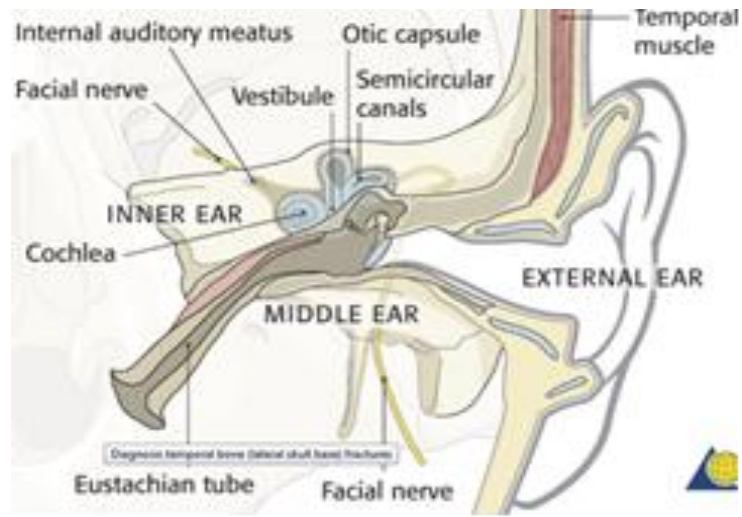

Gambar 6. Anatomi saraf fasialis (Hubungan dengan struktur sekitar) ${ }^{11}$

Di dalam tulang temporal, saraf fasialis memberikan 3 cabang penting yaitu nervus petrosus superior mayor yang memberikan rangsangan untuk sekresi pada kelenjar lakrimal, nervus stapedius yang mensarafi muskulus stapedius dan korda timpani yang memberikan serabut perasa pada duapertiga lidah bagian depan. $^{10}$

Paralisis saraf fasialis merupakan salah satu komplikasi dari fraktur tulang temporal disamping adanya gangguan pendengaran, kebocoran cairan serebrospinal, stenosis kanalis akustikus eksternus, terbentuknya kolesteatom dan cedera vaskuler. ${ }^{5,12}$

Terdapat beberapa klasifikasi fraktur temporal. Pada tahun 1926, Ulrich seperti dikutip oleh March dan Meyers13 pertama kali membagi fraktur tulang temporal menjadi 2, yaitu fraktur longitudinal dan transversal. Klasifikasi lainnya adalah berdasarkan keterlibatan kapsul otik. Fraktur yang tidak melibatkan kapsul otik berjalan anterolateral dari kapsul otik akibat benturan di daerah temporoparietal. Sedangkan fraktur yang melibatkan kapsul otik terjadi akibat benturan pada daerah oksipital yang berjalan 
melintasi kapsul otik sehingga merusak koklea dan labirin. Sampai saat ini klasifikasi menurut Ulrich yang paling sering dipakai. ${ }^{5,13}$

Fraktur longitudinal lebih sering ditemukan dibandingkan fraktur transversal, meliputi $80 \%$ dari seluruh fraktur tulang temporal. Fraktur jenis ini terjadi akibat benturan di daerah temporal atau parietal yang kemudian merambat ke daerah mastoid atau tulang skuamosa. Garis fraktur yang terjadi akan paralel/sejajar dengan aksis panjang piramid petrosa. Garisnya berawal dari pars skuamosa (mastoid atau kanalis auditorius eksterna) meluas melalui posterosuperior liang telinga bagian tulang, selanjutnya melintasi atap telinga tengah di anterior labirin, dan berakhir di anteromedial fossa kranii media dekat foramen laserum dan ovale. ${ }^{5,6,13}$

Gejala klinis fraktur longitudinal tulang temporal meliputi perdarahan dari liang telinga akibat laserasi kulit liang telinga atau membran timpani, hemotimpanum, fraktur kanalis akustikus eksternus, tuli konduktif akibat kerusakan rangkaian tulang pendengaran dan cedera saraf fasialis. Sekitar 20\% fraktur longitudinal akan mengakibatkan cedera pada saraf fasialis. Lokasi saraf fasialis yang terkena biasanya pada segmen horizontal di distal ganglion genikulatum. ${ }^{5,6,13}$

Fraktur transversal meliputi sekitar 20\% dari semua fraktur tulang temporal. Fraktur jenis ini biasanya terjadi akibat benturan pada daerah frontal atau parietal, tetapi dapat juga terjadi akibat benturan pada daerah oksipital. Garis fraktur berjalan tegak lurus piramid petrosa, dimulai dari fossa kranii media (dekat foramen laserum dan spinosum) kemudian melintasi piramid petrosa dan $\mathrm{KAl}$, hingga berakhir di foramen magnum. ${ }^{5,6,13}$

Pada fraktur transversal, biasanya terjadi kerusakan pada koklea dan struktur vestibuler yang mengakibatkan tuli sensorineural dan vertigo. Sedangkan cedera pada saraf fasialis terjadi sekitar $50 \%$ kasus. Lokasi cedera biasanya pada daerah kanalis auditori interna sampai segmen horizontal di distal ganglion genikulatum. ${ }^{5,6,13}$

Pada kasus ini, cedera saraf fasialis terjadi akibat fraktur longitudinal tulang temporal, dimana dari anamnesis didapatkan benturan terjadi pada daerah temporoparietal, terdapat riwayat keluar darah dari telinga dan pada pemeriksaan fisik terlihat laserasi pada liang telinga serta adanya hemotimpanum. Pemeriksaan penala dan audiometri didapatkan kesimpulan tuli konduktif.

Pemeriksaan saraf fasialis perlu dilakukan untuk melihat derajat, letak lesi, dan prognosis penyakit. Penilaian saraf fasialis yang cukup sering digunakan adalah sistem House-Brackmann yang terdiri dari 6 derajat dimana derajat I menunjukkan fungsi saraf wajah normal dan derajat VI menunjukkan paralisis total. ${ }^{5-8}$

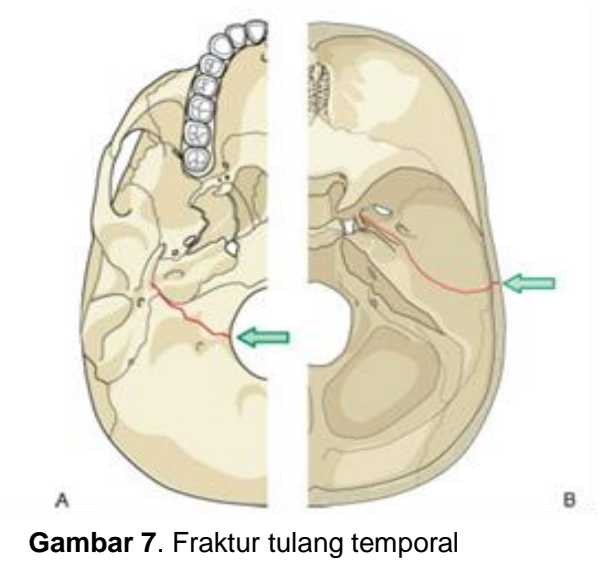

A. Transversal B. Longitudinal ${ }^{6}$

Penilaian lain menggunakan sistem Freys yang terdiri dari 4 komponen, yaitu pemeriksaan fungsi motorik pada 10 otot wajah, tonus, sinkinesis, dan hemispasme. Pemeriksaan untuk menentukan letak lesi meliputi tes Schimmer, refleks stapedius dan gustatometri. ${ }^{5-8,12,13}$

Pada pasien ini dari pemeriksaan saraf fasialis pada saat datang ke IGD didapatkan kesimpulan paresis saraf fasialis perifer dextra dengan fungsi motorik yang masih baik $66 \%$, House Brackmann III dengan lesi setinggi infragenikulatum. Letak pasti lesi pada pasien ini tidak bisa ditentukan karena tidak dilakukan pemeriksaan refleks stapedius akibat adanya laserasi pada liang telinga dan terdapat hemotimpanum yang baru bisa terdeteksi setelah rawatan hari ke-3.

Pemeriksaan CT Scan dengan resolusi tinggi sangat membantu dalam menegakkan diagnosis fraktur tulang temporal, dan juga untuk menilai keutuhan osikel atau tulang-tulang pendengaran. CT Scan resolusi tinggi dapat menggambarkan jenis dan lokasi fraktur sehingga dapat membantu operator dalam perencanaan operatif jika dibutuhkan. 
Sedangkan pemeriksaan Magnetic Resonance Imaging (MRI) masih kontroversi. MRI lebih baik dibandingkan CT Scan dalam membedakan perdarahan dengan udem mukosa pada air cell mastoid atau cairan serebrospinal pada telinga tengah dan mastoid. ${ }^{6,7,12,13}$

Uji elektrodiagnostik seperti Nerve Exitability Test (NET), Maximal Stimulation Test (MST), Electroneurography (ENoG) dan Electromyography (EMG), bermanfaat untuk menilai derajat kerusakan, mentukan prognosis perbaikan saraf fasialis pasca trauma serta merencanakan terapi yang akan diberikan. ${ }^{6-8,12,13}$

Pemeriksaan ENoG merupakan salah satu tes elektrofisiologis yang dianggap oaling akurat dalam menentukan prognosis cedera saraf fasialis berdasarkan degenerasi saraf. $^{3}$

Penatalaksanaan paresis saraf fasialis akibat fraktur tulang temporal masih merupakan hal yang kontroversial. Chen dan Ariaga ${ }^{14}$ menyatakan pasien dengan paralisis parsial (House Brackmann II-V) cukup dilakukan observasi dan terapi dengan steroid berupa prednison $1 \mathrm{mg} / \mathrm{kg}$ berat badan/hari selama 10 hari tappering off jika tidak terdapat kontraindikasi. Sedangkan pada paralisis komplit (House Brackmann VI), terapi medikamentosa dengan steroid dapat dikombinasikan dengan terapi bedah berupa dekompresi atau grafting. Akan tetapi pertimbangan untuk melakukan pembedahan tergantung dari pemeriksaan CT Scan dan tes elektrofisiologis. Terapi bedah dilakukan jika pada pemeriksaan CT Scan ditemukan adanya fraktur temporal disertai diastasis $>1 \mathrm{~mm}$ dan pemeriksaan EnOG menunjukkan degenerasi $>90 \%$.

Fish seperti yang dikutip Gantz ${ }^{15}$ menyatakan terapi bedah dilakukan pada pasien dengan hasil pemeriksaan EnOG menunjukkan degenerasi $>90 \%$ dalam waktu 6 hari setelah kejadian. Pembedahan ditunda sampai 3 minggu untuk mengurangi edema dan hematom yang terjadi sehingga lapangan operasi terlihat lebih jelas.

Chang dan Cass seperti dikutip Kevin dan Makishima $^{12}$ menyimpulkan bahwa pasien dengan paralisis saraf fasialis yang tidak perlu dilakukan terapi bedah adalah: 1) fungsi saraf fasialis yang normal setelah trauma, 2) paralisis inkomplit, selama tidak terdapat perubahan menjadi paralisis komplit, dan 3) degenerasi yang kurang dari 95\% pada pemeriksaan ENoG.

Pertimbangan untuk melakukan pembedahan atau terapi medikamentosa pada cedera saraf fasialis tergantung onset terjadinya paralisis setelah trauma, yaitu onset cepat (paralisis yang terlihat dalam beberapa jam pertama) atau lambat (dalam hitungan hari atau minggu). ${ }^{6}$ Turner seperti dikutip Diaz ${ }^{15}$ yang melakukan penelitian pada 52 kasus cedera fasialis pada fraktur temporal menyimpulkan bahwa perbaikan komplit terjadi pada 94\% kasus dengan onset lambat dan $75 \%$ pada kasus dengan onset cepat. Sedangkan McKennan dan Chole yang meneliti 36 kasus (17 kasus onset cepat dan 19 onset lambat), menemukan 94\% kasus dengan onset lambat mengalami perbaikan komplit dan sisanya perbaikan inkomplit (HB II), sedangkan 8 dari kasus onset cepat berupa saraf yang terputus. ${ }^{16}$

Chang dan Cass seperti dikutip Kevin dan Makishima $^{12}$ mengemukakan suatu algoritma penatalaksanaan cedera saraf fasialis akibat trauma berdasarkan onset kejadian paralisis dan hasil pemeriksaan ENoG (Algoritma 8).

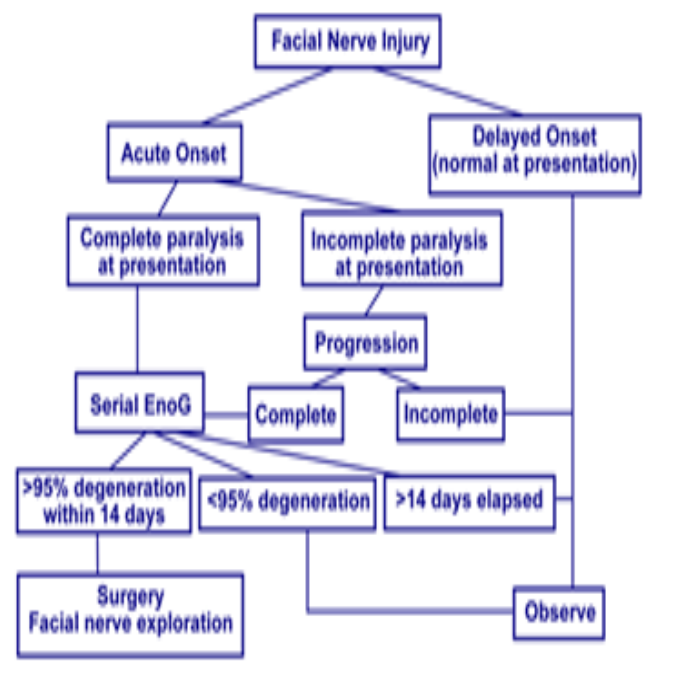

Gambar 8. Algoritma penatalaksanaan cedera saraf fasialis ${ }^{12}$

Terapi konservatif yang dapat diberikan pada cedera saraf fasialis akibat trauma adalah pemberian steroid, melindungi fungsi penglihatan dan terapi rehabilitasi wajah. Pemberian steroid dapat berupa kortikosteroid dosis tinggi untuk mengurangi edema yang terjadi. Chen dan Ariaga ${ }^{14}$ menyarankan pemberian prednison $1 \mathrm{mg} / \mathrm{kg} /$ hari selama 10 hari 
dengan tappering off. Sedangkan Chang dan Cass, seperti dikutip Patel dan Groppo ${ }^{6}$ menyatakan pemberian kortikosteroid intravena jangka pendek dapat mencegah inflamasi serta mengurangi edema pada saraf dan daerah sekitarnya, sehingga mengurangi kompresi pada saraf.

Mata yang tidak menutup sempurna dalam waktu lama dapat mengakibatkan keratitis. Tindakan pencegahan yang dapat dilakukan antara lain pemberian airmata artifisial, membantu menutup mata dengan cara sederhana dengan plester saat tidur hingga diberi implan pemberat (gold weighting) atau dilakukan tarsorafi oleh dokter mata. ${ }^{9}$

Pada kasus ini diberikan terapi konservatif dengan pemberian kortikosteroid injeksi (deksametason) tappering off, dimana selama observasi pada saat rawatan, pasien mengalami kemajuan pada fungsi motorik dari $68 \%$ pada saat masuk menjadi $74 \%$ pada saat pasien pulang paksa dan tidak menunjukkan perubahan ke arah paralisis komplit. Satu tahun kemudian terdapat perbaikan fungsi motorik menjadi 94\%, House Brackman II. Hal ini sesuai dengan beberapa kepustakaan yang menyatakan bahwa paralisis inkomplit saraf fasialis yang terdapat kemajuan pada fungsi saraf motorik, cukup dilakukan observasi dan terapi simptomatis tanpa pembedahan.

Ketika diputuskan untuk melakukan tindakan operatif untuk dekompresi saraf fasialis, fungsi pendengaran dan keseimbangan harus diperhitungkan. Pendekatan operasi untuk cedera saraf fasialis bervariasi meliputi transmastoid, translabirin dan fossa media. Jika fungsi pendengaran dan keseimbangan baik maka pendekatan yang dipakai adalah transmastoid/fossa media. Jika fungsi pendengaran dan keseimbangan terganggu, direkomendasikan untuk menggunakan pendekatan transmastoid/translabirin. ${ }^{3}$

Tujuan tindakan operasi pada kasus terpotongnya nervus fasialis yang komplit adalah untuk memperbaiki fungsi saraf dengan mengurangi terjadinya fibrosis dan inflamasi, serta memberikan penyambungan yang cepat di ujung saraf. Tujuan ini dapat dicapai dengan melakukan jahitan neurorafi atau dengan fibrin glue untuk memberikan anastomosis ujung ke ujung. Pemulihan fungsi fasialis setelah tindakan membutuhkan proses panjang yang biasanya hingga 7 bulan. ${ }^{15}$

\section{DAFTAR PUSTAKA}

1. Kosins AM, Hurvitz KA, Evans GRD, Wirth GA. Facial paralysis for the plastic surgeon. Can J Plast Surg. 2007; 15(2): 77-82.

2. Myckatyn TM, Mackinnon SE. A review of facial nerve anatomy. Seminars in plastic surgery 2004; 18(1): 5-10.

3. Gleinser David, Makishima T. Facial nerve trauma. [last revised June 29, 2009; cited Dec 20, 2011]. Available from: http://www.utmb.edu/otoref/grnds/facialnerve-trauma-090629.

4. Kim JYS, Narayan D. Facial nerve paralysis. [last revised Apr 5, 2011; cited Dec 23, 2011]. Available from: http://emedicine.medscape.com/article/12905 471.

5. Cineu R, Agrawal A, Baishakhiya N. Understanding temporal bone fractures. Pakistan Journal of Otolaryngology 2008; 23: 42-4.

6. Patel A, Groppo E. Management of temporal bone trauma. Craniomaxillofacial Trauma \& Reconstruction 2010; 3(2): 103-13.

7. Chan EH, Tan HM, Tan TY. Facial palsy from temporal bone lesion. Annals Academy of Medicine 2005; 34(4): 322-9.

8. Massa N, Meyers AD. Intratemporal bone trauma. [last revised Feb 29, 2011; cited Dec 21, 2011]. Available from: http://emedicine.medscape.com/article/84622 6.

9. Mavrikaskis J. Facial nerve palsy: Anatomy, etiology, evaluation, and Management. Orbit 2008; 27: 466-74.

10. Sjarifuddin, Bashiruddin J, Bramantyo B. Kelumpuhan nervus fasialis perifer. Dalam: Soepardi EA, Iskandar N, Bashiruddin J, Restuti RD, editor. Buku ajar ilmu kesehatan tenggorok kepala \& leher. Edisi ke 6. Balai Penerbit FK-UI: Jakarta; 2007. p. 114-7.

11. Bergman RA, Afifi AK. Atlas of human anatomy: The left middle ear with the facial 
nerve in the facial canal. Available from: www.anatomyatlases.org

12. Kevin $\mathrm{KH}$, Makishima T. Temporal bone fracture. [last revised Oct 12, 2005; cited Dec 21, 2011]. Available from: http://www.utmb.edu/otoref/grnds/Tempbone-trauma-051012.

13. March AR, Meyers AD. Temporal Bone fracture. [last revised June 4, 2011; cited Dec 21, 2011]. Available from: http://emedicine.medscape.com/article/85736 5.

14. Chen DA, Ariaga MA. Acute facial paralysis.
In: Pensak ML, ed. Controversies in otolaryngology. New York: Thieme; 2001: p. 227-31.

15. Gantz BJ, Rubinstein JT, Samy RN. Intratemporal facial nerve surgery. In: Cumming $\mathrm{CW}$ et al editors. Cumming otolaryngology head \& neck surgery, 4th ed. Philadelphia: Elsevier Mosby; 2005: p. 335472.

16. Diaz R, Brodie H. Middle ear and temporal bone trauma. In: Bailey BJ, Johnson JT edsCase. Head and neck surgeryotolaryngology. Lippincott William: 2006: p 2059-77. 